\title{
Training and expectations on job mobility in the call centres sector
}

Citation for published version (APA):

Sieben, I. J. P., \& de Grip, A. (2004). Training and expectations on job mobility in the call centres sector. Journal of European Industrial Training, 28(2/3/4), 257-271. https://doi.org/10.1108/03090590410527645

Document status and date:

Published: 01/01/2004

DOI:

10.1108/03090590410527645

Document Version:

Publisher's PDF, also known as Version of record

\section{Please check the document version of this publication:}

- A submitted manuscript is the version of the article upon submission and before peer-review. There can be important differences between the submitted version and the official published version of record.

People interested in the research are advised to contact the author for the final version of the publication, or visit the DOI to the publisher's website.

- The final author version and the galley proof are versions of the publication after peer review.

- The final published version features the final layout of the paper including the volume, issue and page numbers.

Link to publication

\footnotetext{
General rights rights.

- You may freely distribute the URL identifying the publication in the public portal. please follow below link for the End User Agreement:

www.umlib.nl/taverne-license

Take down policy

If you believe that this document breaches copyright please contact us at:

repository@maastrichtuniversity.nl

providing details and we will investigate your claim.
}

Copyright and moral rights for the publications made accessible in the public portal are retained by the authors and/or other copyright owners and it is a condition of accessing publications that users recognise and abide by the legal requirements associated with these

- Users may download and print one copy of any publication from the public portal for the purpose of private study or research.

- You may not further distribute the material or use it for any profit-making activity or commercial gain

If the publication is distributed under the terms of Article $25 \mathrm{fa}$ of the Dutch Copyright Act, indicated by the "Taverne" license above, 


\title{
Training and expectations on job mobility in the call centres sector
}

Training and expectations

\author{
Inge Sieben and Andries de Grip \\ Research Centre for Education and the Labour Market (ROA), \\ Maastricht University, Maastricht, The Netherlands
}

Keywords Training, Job mobility, Call centres, The Netherlands

Abstract Analyses whether the participation of workers in general, sector-specific, and firm-specific training affects their expectations on job mobility within or outside the call centres sector. Distinguishes between the perceived difficulty to find an equally attractive job and the inclination to quit for another job. Employing data on 525 call centre agents working in eight call centres in The Netherlands, finds that training does not significantly affect the perceived labour market perspectives of call centre agents, nor influence expected job mobility inside or outside the sector. The inclination to quit the present job within two years is the same for agents with and without training. There is one exception, however. Agents who followed firm-specific training significantly less often considered quitting for a job in another call centre. All this is good news for firms offering training. Another finding, however, might be more problematic. The work experience of agents positively affects their labour market perspectives inside the sector. In addition, agents with more experience are more inclined to quit for a job in another call centre. This means that firms need to keep their employees satisfied.

\section{Introduction}

Workers and firms have different interests in investing in a worker's skills. In the short-run, these interests are not conflicting. Workers need skills to perform adequately in their jobs and firms want to increase their productivity by employing qualified workers. The long-term interests of workers and firms, however, might differ, since workers may use their skills to enhance their external labour market perspectives. Firms, on the other hand, want to keep these qualified workers tied to the firm. Workers and firms may therefore differ in their willingness to invest in training.

It is important in this respect to differentiate between general, or transferable, training and firm-specific training. In case of firm-specific training under-investment in training may occur due to a "hold-up" problem, as firms will hesitate to invest in firm-specific training because this strengthens the bargaining position of workers. In case of general or transferable training under-investment may occur due to poaching problems as often firms may attempt to recruit workers with these transferable skills. Moreover, the workers are reluctant to invest in these skills due to credit constraints and the uncertainty they face with respect to future benefits (e.g. Stevens, 1994, 1999; Acemuglu and Pischke, 1999). Non-optimal investments in transferable training particularly hold for vocational training that is relevant in a particular

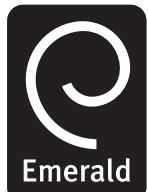

Received September

2003

Revised November 2003

Accepted December 2003 
JEIT

$28,2 / 3 / 4$

258 sector of industry. As Franz and Soskice (1995) and Acemuglu and Pischke (1998) show this may result in multiple equilibriums. If firms gain information about the quality of the workers during the training and offer employment to all good workers, competing firms know that only the less productive "lemons" are searching for another job. However, if the skills of trained workers are more transparent for other firms, there will be equilibrium with high quits and a low level of training.

The latter explains that in many countries sector specific vocational education is part of initial full-time education paid by the government. However, newly emerging sectors of industry usually do not have their sector specific vocational training established in initial education (yet). For this reason firms in a fast growing new branch as the call centres sector have no alternative. They have to train their workers if particular sector specific vocational skills are required for an adequate performance in the job. The same holds for workers that are searching for a job in this sector. They have to invest in these skills in order to perform the job adequately. This means that both firms and workers have a short-time interest to invest in specific skills in this sector.

However, the long-term interest of workers and firms might be conflicting. Workers who acquired sector specific skills gain from the option to quit and apply for a job in a competing firm, whereas the firm who trained the worker has an interest to keep the more competent workers. One may wonder, however, how attractive it would be for a worker to switch to a firm that poaches their skilled workers from other firms. Firms that invest in the skills of their workers signal that they are "investors in people". Particularly in sectors of industry where technological and organisational changes occur frequently, workers will be probably more inclined to stay employed in a firm that offers attractive training facilities.

In this paper, we will analyse whether the participation of workers in general, sector-specific, and firm-specific training affects their expectations on job mobility within or outside the call centres sector. As mentioned, the call centre sector is an interesting sector in this respect, since firms are forced to offer training due to the lack of specific vocational training in initial education. Moreover, the sector is a fast-growing branch of industry with a high level of personnel turnover. The job commitment among call centre agents traditionally is quite low (Rose, 2002), which places the problem of tying workers to the firm prominently on the firms' human resource management (HRM) agenda.

\section{Training and expectations on job mobility}

Theories on training and job mobility have been developed from different scientific perspectives. In sociological literature, the focus is on characteristics of workers and firms when explaining training and mobility patterns of workers. The HRM literature stresses the importance of workers' job 
satisfaction. In this paper, we derive our key hypotheses on job mobility inside and outside the sector from economic human capital theory. From this point of view, training is an investment in human capital. The implications of this training for the job mobility of workers depend on the nature of the investment (Becker, 1962): general, sector-specific, or firm-specific training.

The link between training and job mobility is perhaps the most obvious in the case of firm-specific training. Following this kind of training, workers learn skills that are of use in the firm in which they are presently employed, like knowledge on a specific product. In order to profit from the training, they have to stay employed in the firm, since these skills cannot be deployed in other firms. This implies that workers who follow firm-specific training will not leave their firm for another job inside or outside the sector:

H1a. Firm-specific training will decrease the expected job mobility of workers inside the sector.

H1b. Firm-specific training will decrease the expected job mobility of workers outside the sector.

Sector-specific training, on the other hand, is related to the concept of transferable training, which is of value in a small number of firms (Stevens, 1999). Workers participating in sector-specific training, thus, acquire skills that are not only useful in their own firm, but also in other firms in their sector. These skills are practically worthless in jobs outside the sector, though. Workers with sector-specific training will, therefore, be mobile inside their sector, but not outside their sector:

H2a. Sector-specific training will increase the expected job mobility of workers inside the sector.

H2b. Sector-specific training will decrease the expected job mobility of workers outside the sector.

Finally, general training will increase the more transferable skills of workers, like their language skills, computer skills, or problem solving techniques. These skills are not limited to one firm or one sector, but are useful in many jobs and sectors. General training, therefore, will increase the job mobility of workers, in particular outside the sector:

$H 3 a$. General training will increase the expected job mobility of workers inside the sector.

$H 3 b$. General training will increase the expected job mobility of workers outside the sector.

Most empirical studies find that general training typically does not affect job mobility, whereas specific training reduces the probability of quitting a job (for an overview, see Stromback, 2002). No distinction is made between

\section{Training and expectations}

259 
JEIT

$28,2 / 3 / 4$

260

sector-specific and firm-specific training nor between job mobility inside and outside the sector, however.

In this paper, we focus on the mobility expectations of call centre agents, that is on their perceived opportunities for improvement by quitting to another job. By looking at workers' perceptions on career advancement we are able to distinguish between the perceived difficulty to find an equally attractive job and the inclination to quit for another job. This distinction could be highly relevant. The perceived difficulty to find an equally attractive job can be interpreted as the worker's perception of the opportunities in the labour market of someone with the worker's competencies, i.e. the option value of a worker's human capital (Dothan and Williams, 1991). However, if workers have good opportunities in the external labour market, this does not mean that they are really inclined to quit for another job, as workers could be quite satisfied with their current jobs and opportunities for advancement in the firm where they are employed now. Measuring the worker's inclination to quit for another job is thus closely related to the concept of job commitment.

As job mobility is not influenced by training only, we also pay attention to characteristics of workers, jobs and firms. In the first place, work experience negatively affects job mobility (De Grip et al., 1998). Workers accumulate specific skills during their work life, which makes it more difficult for them to switch jobs, especially outside the sector. This implies that it also important to look at the skills of workers, but research on this topic is scarce. Moreover, we expect that workers with gaps in firm-specific or sector-specific skills are more inclined to quit their job in favour of a job outside the sector, whereas workers with gaps in general skills will not be so mobile. In addition, job mobility is influenced by worker, job, and firm characteristics like sex, age, educational level, field of study, working part-time, type of contract (permanent versus temporary) and firm size. Since many of these characteristics not only affect job mobility but also training participation, it is important to control for these variables in the analysis (see Zwick, 2002).

\section{Data}

In order to test our hypotheses on the relation between training and expectations on job mobility, we employ data on call centre agents [1] working in eight call centres, gathered in September and October 2001[2]. 525 agents returned the written questionnaires, yielding a response rate of 48 per cent. We excluded students and those working less than 16 hours per week, since their jobs cannot be considered to be their main activity. Next to the call centre agents, their managers filled in additional questionnaires on specific firm characteristics. All eight participating call centres are situated in the region Arnhem/Nijmegen in The Netherlands, which is known for its high density in call centres. The call centres can be regarded as representative for the call centre sector since they differ in important aspects like firm size and services 
(complaints desk, sales and booking office, help line, database enrichment and control, etc.).

Table I gives an overview of some background characteristics of the call centre agents. It is these personal, job, and firm characteristics that will be included in our analyses [3]. It turns out that 55 per cent of the call centre agents are women. The average age being 31 years, agents are relatively young workers, although about one out of four is older than 40 years. The agents' educational backgrounds are quite mixed. Most of them followed secondary education, often in the field of economics. A total 20 per cent have a vocational college or university degree. The large number of high-level educational institutions in the region might explain this remarkably high percentage. Of the call centre agents, 56 per cent work on a part-time basis, that is less than 36 hours a week. The majority has a permanent contract, or a temporary contract with the prospect of a permanent one. Contracts on call are quite rare in the Dutch call centre sector (2 per cent). Many agents are rather inexperienced in their job; 32 per cent has even worked less than a year in a call centre. On average, the relevant work experience of call centre agents is 3.5 years. The average gross income is about $€ 1,625$ per month on a full-time basis.

The last column of Table I shows some important firm characteristics. Almost every call centre agent works in a contact centre that is part of the firm it serves (in-house) [4]. Only 6 per cent work in so-called outsourcing contact

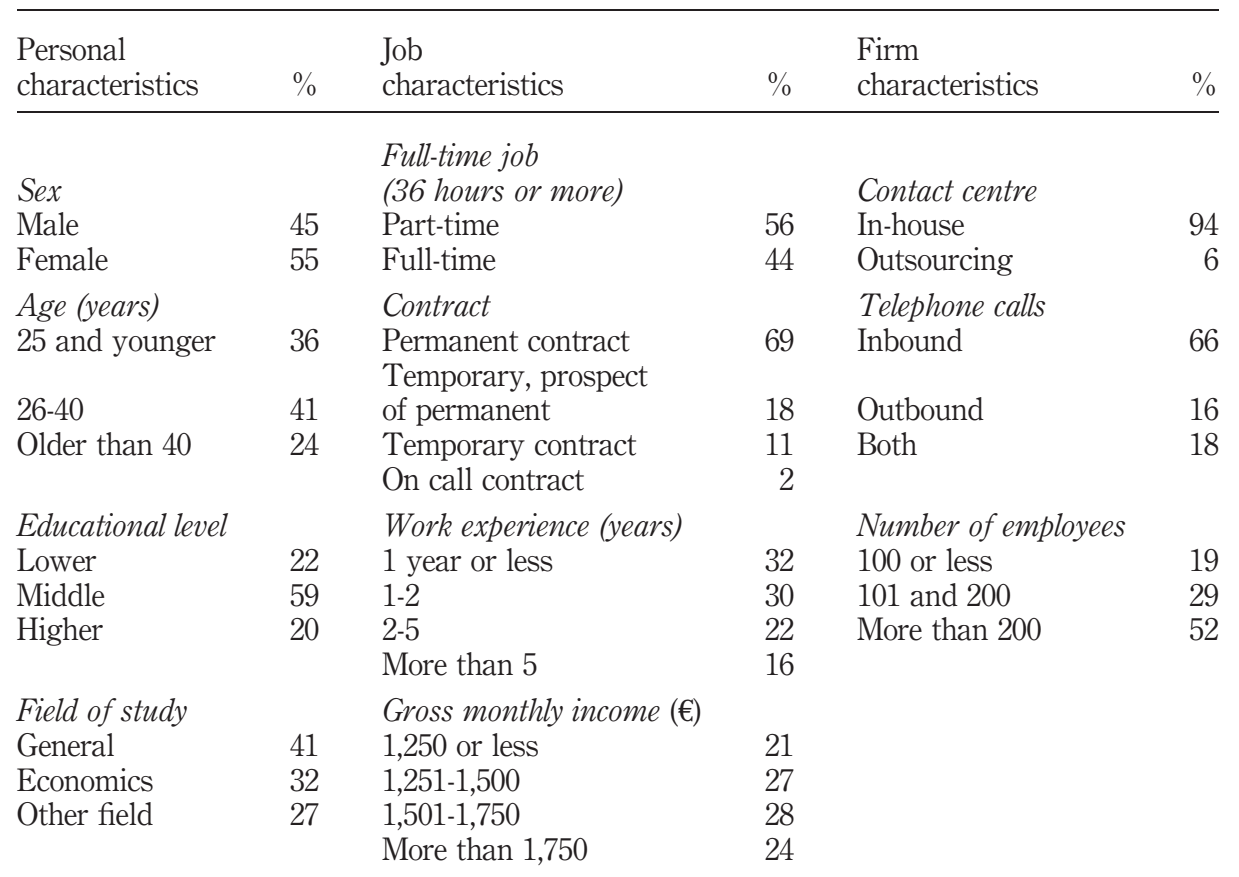

Training and expectations

261 
JEIT

$28,2 / 3 / 4$

262

centres. Two-thirds of all agents make inbound telephone calls only. This means that customers contact the call centre and are helped by an agent. 16 per cent of the agents make outbound telephone calls in which they phone the customer. 18 per cent deals with both inbound and outbound telephone calls. Finally, about half of the agents work in a large call centre with more than 200 employees. Figures from the NCCBP (2001) show that call centres in the region Arnhem/Nijmegen are relatively large compared to other regions in The Netherlands.

Table II shows that 63 per cent of the call centre agents participated in some kind of training during the past year. This percentage is quite high keeping in mind that about 40 per cent of Dutch workers participated in training in this period (ROA, 2000). A total of 44 per cent of the agents followed training in a more general field, like problem solving, coping with stress, dealing with anger and aggression, negotiation techniques, computer skills, or knowledge of foreign languages. Sector-specific training also is quite popular (43 per cent). This kind of training focuses on skills like customer friendliness, basic conversational techniques, work procedures and telephonic sales techniques. Finally, firm-specific training comprises of product knowledge and firm knowledge. These skills are the least transferable to other jobs.

In our analyses, we also include three measures of skill gaps: general, sector-specific, and firm-specific skill gaps. These measures are constructed by combining the (bad) scores of call centre agents on general, sector-specific, and firm-specific skills with the importance that their managers attach to these skills. The first column in Table III gives the percentage of agents with a bad score (self-reported score of 1 or 2 on a range of 5) on 13 skills. These scores are

\begin{tabular}{lr}
\hline Training & $\%$ \\
\hline General training & 44 \\
Problem solving & 18 \\
Coping with stress & 6 \\
Dealing with anger and aggression & 13 \\
Negotiation techniques & 8 \\
Computer skills & 34 \\
Knowledge of foreign languages & 4 \\
Sector-specific training & 43 \\
Customer friendliness & 22 \\
Basic conversational techniques & 27 \\
Work procedures & 22 \\
Telephonic sales techniques & 28 \\
Firm-specific training & 35 \\
Product knowledge & 30 \\
Firm knowledge & 19 \\
Total & 63
\end{tabular}

Table II.

Percentage of call centre agents following training during the past year $(n=408)$

\section{$\%$}




\begin{tabular}{|c|c|c|c|c|}
\hline & $\begin{array}{l}\text { Agents with } \\
\text { bad score \% }\end{array}$ & $\begin{array}{l}\text { Managers' score } \\
\text { on importance }\end{array}$ & $\begin{array}{c}\text { Agents with } \\
\text { skill gaps } \\
\%\end{array}$ & $\begin{array}{l}\text { Training and } \\
\text { expectations }\end{array}$ \\
\hline General skills & - & - & 39 & \\
\hline Problem solving & 4 & 4.2 & - & \\
\hline Coping with stress & 5 & 3.8 & - & 263 \\
\hline Dealing with anger and aggression & 7 & 3.8 & - & \\
\hline Negotiation techniques & 18 & 2.6 & - & \\
\hline Computer skills & 4 & 4.7 & - & \\
\hline Knowledge of foreign languages & 21 & 2.9 & - & Table II \\
\hline Sector-specific skills & - & - & 35 & Percentage of agents \\
\hline Customer friendliness & 3 & 4.9 & - & with bad score on skills, \\
\hline Basic conversational techniques & 2 & 4.4 & - & managers' score on \\
\hline Work procedures & 8 & 3.3 & - & skills' importance \\
\hline Telephonic sales techniques & 32 & 3.7 & - & (five-point scale from \\
\hline Firm-specific skills & - & - & 20 & 1 to 5), and percentage \\
\hline Product knowledge & 11 & 4.7 & - & of agents with skill gaps \\
\hline Firm knowledge & 16 & 4.0 & - & $(n=408)$ \\
\hline
\end{tabular}

multiplied by the importance managers attach to these skills in adequately performing as a call centre agent (importance score on a five point scale). The underlying argument is that bad scores on skills only matter if these skills are needed in the job. A worker's general skill gaps is then a dichotomised measure made up of the underlying gaps on problem solving, coping with stress, dealing with anger and aggression, negotiation techniques, computer skills, and knowledge of foreign languages. A comparable strategy is followed for the sector-specific and firm-specific skill gaps. The last column of Table III gives the percentage of agents with general, sector-specific, and firm-specific skill gaps.

\section{Effects of training on labour market perspectives}

The labour market perspectives of call centre agents are measured by asking them how difficult they think it is to find an equally attractive job at another call centre or outside the sector. Figure 1 shows that 22 per cent of the call centre agents think it is (very) difficult to find an equally attractive job in the call centre sector, whereas 25 per cent think it to be (very) difficult to find such a job outside the sector.

Does general, sector-specific, or firm-specific training influence these perceived labour market perspectives as we hypothesised? The first columns in Table IV show the estimation results of a model with training as the only explanation for labour market perspectives inside the sector (Model I). Contrary to our expectations $(H 2 a)$, agents who followed sector-specific training think it to be more difficult to find an equally attractive job at another call centre than agents who did not participate in this kind of training. This is quite 
JEIT

$28,2 / 3 / 4$

\section{4}

Figure 1.

Perceived difficulty in finding an equally attractive job inside or outside the call centre sector $(n=408)$

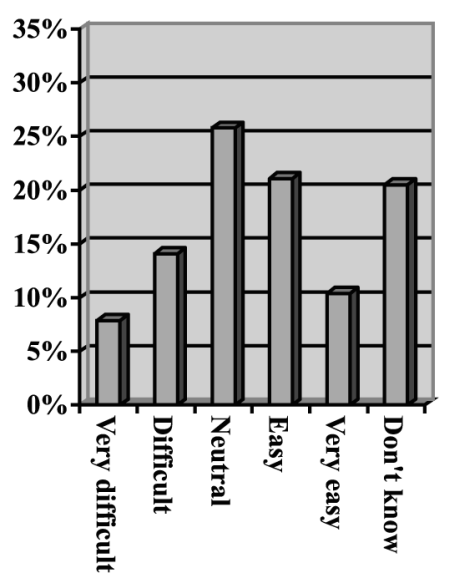

Outside call centre sector

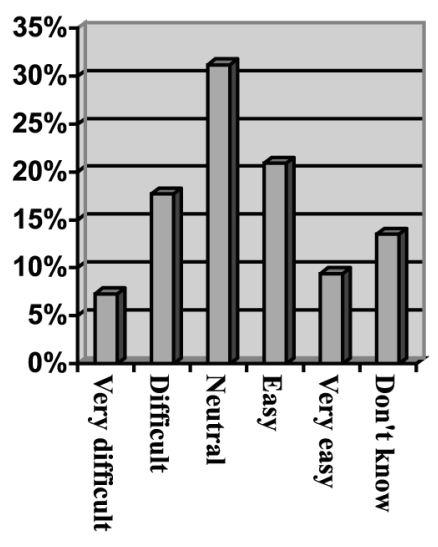

remarkable, since sector-specific training is thought to increase skills that can be deployed in all firms in the sector. General and firm specific training, however, do not significantly influence the perceived labour market perspectives of the agents within the call centre sector. The effects of training on the perspectives outside the sector also are not in line with our hypotheses. General and sector-specific training do not affect these perspectives, whereas firm-specific training decreases the perceived difficulty to find an equally attractive job outside the sector.

Model I is not complete, however. As we mentioned in the theoretical part of this paper, labour market perspectives are not influenced by training only, but also by characteristics of workers, jobs and firms. Therefore, in Model II, we included sex, age, work experience, working hours, type of contract, educational level and field of study of call centre agents. In addition, we incorporated the three measures of skill gaps: general, sector-specific, and firm-specific skill gaps Finally, we included some characteristics of firms: type of contract centre, number of employees and type of telephone calls.

The results of these extended analyses are also in Table IV. They show that the effect of sector-specific training on the perceived labour market perspectives inside the call centre sector disappears. General training and firm-specific training does not affect these perspectives either. Agents with more work experience, however, think it to be less difficult to find an equally attractive job in another call centre. It seems that these agents increase their option-value on the call centre market by accumulating skills through learning on-the-job. This effect is smaller for agents with many years of experience, though, implying that there is an upper limit to it. In addition, agents with general skill gaps think that it is more difficult to find an equally attractive job inside the sector than agents without these skill gaps. This implies that general 


\begin{tabular}{|c|c|c|c|c|c|c|c|c|c|}
\hline & Inside & call ce & ntre sector & & Outsic & le call & centre sector & & I raining and \\
\hline & Mod & & Mod & el II & Mod & el I & Mode & & \\
\hline & $B$ & $\mathrm{SE}$ & $B$ & $\mathrm{SE}$ & $B$ & $\mathrm{SE}$ & $B$ & $\mathrm{SE}$ & \\
\hline Intercept & $-0.98 * * *$ & 0.18 & -0.39 & 1.10 & $-0.73 * * *$ & 0.17 & 0.39 & 1.09 & \\
\hline $\begin{array}{l}\text { Training } \\
\text { General }\end{array}$ & -0.33 & 0.33 & -0.42 & 0.40 & 0.18 & 0.30 & 0.26 & 0.39 & 265 \\
\hline Sector-specific & $0.66 * *$ & 0.33 & 0.38 & 0.41 & 0.06 & 0.30 & -0.38 & 0.39 & \\
\hline Firm-specific & -0.40 & 0.32 & -0.20 & 0.39 & $-0.67 * *$ & 0.30 & -0.29 & 0.38 & \\
\hline Sex & & & & & & & & & \\
\hline Female & & & -0.47 & 0.34 & & & 0.10 & 0.33 & \\
\hline Male (ref.) & & & - & - & & & - & - & \\
\hline Age (years) & & & & & & & & & \\
\hline Less then 25 & & & 0.49 & 0.51 & & & $-1.52^{* * *}$ & 0.48 & \\
\hline $26-40$ & & & -0.67 & 0.51 & & & $-1.30 * * *$ & 0.44 & \\
\hline 40 and older (ref.) & & & - & - & & & - & - & \\
\hline Work experience & & & & & & & & & \\
\hline In years & & & $-0.21^{*}$ & 0.12 & & & -0.06 & 0.11 & \\
\hline In years $^{2}$ & & & $0.01 * *$ & 0.00 & & & 0.01 & 0.01 & \\
\hline Working hours & & & & & & & & & \\
\hline Part-time job & & & -0.04 & 0.33 & & & -0.10 & 0.34 & \\
\hline Full-time job (ref.) & & & - & - & & & - & - & \\
\hline Type of contract & & & & & & & & & \\
\hline Permanent & & & -0.08 & 0.35 & & & -0.07 & 0.36 & \\
\hline Temporary (ref.) & & & - & - & & & - & - & \\
\hline Educational level & & & & & & & & & \\
\hline Lower & & & 0.26 & 0.60 & & & $1.45^{* *}$ & 0.60 & \\
\hline Middle & & & -0.07 & 0.43 & & & 0.67 & 0.45 & \\
\hline Higher (ref.) & & & - & - & & & - & - & \\
\hline Field of study & & & & & & & & & \\
\hline General & & & -0.48 & 0.44 & & & -0.64 & 0.42 & \\
\hline Economics & & & -0.28 & 0.39 & & & -0.37 & 0.39 & \\
\hline Other (ref.) & & & - & - & & & - & - & \\
\hline Skill gaps & & & & & & & & & \\
\hline General & & & $0.78^{* *}$ & 0.34 & & & $0.76^{* *}$ & 0.33 & \\
\hline Sector-specific & & & -0.08 & 0.33 & & & 0.02 & 0.33 & \\
\hline Firm-specific & & & 0.01 & 0.41 & & & -0.35 & 0.42 & \\
\hline Type of contact centre & & & & & & & & & Table IV. \\
\hline $\begin{array}{l}\text { In-house } \\
\text { Outsourcing (ref.) }\end{array}$ & & & $\begin{array}{c}-0.50 \\
-\end{array}$ & $\begin{array}{c}0.84 \\
-\end{array}$ & & & -0.91 & $\begin{array}{c}0.84 \\
-\end{array}$ & Results of logistic \\
\hline Number of employees & & & & & & & & & sion analyses on \\
\hline 100 or less & & & 0.10 & 0.43 & & & 0.15 & 0.43 & ercnective. thet \\
\hline $101-200$ & & & 0.01 & 0.49 & & & -0.36 & 0.50 & difficulty of finding an \\
\hline More than 200 (ref.) & & & - & - & & & - & - & equally attractive job \\
\hline & & & & & & & (conti & ued) & $\begin{array}{l}\text { inside and outside the } \\
\text { call centre sector }\end{array}$ \\
\hline
\end{tabular}


JEIT

$28,2 / 3 / 4$

Table IV.

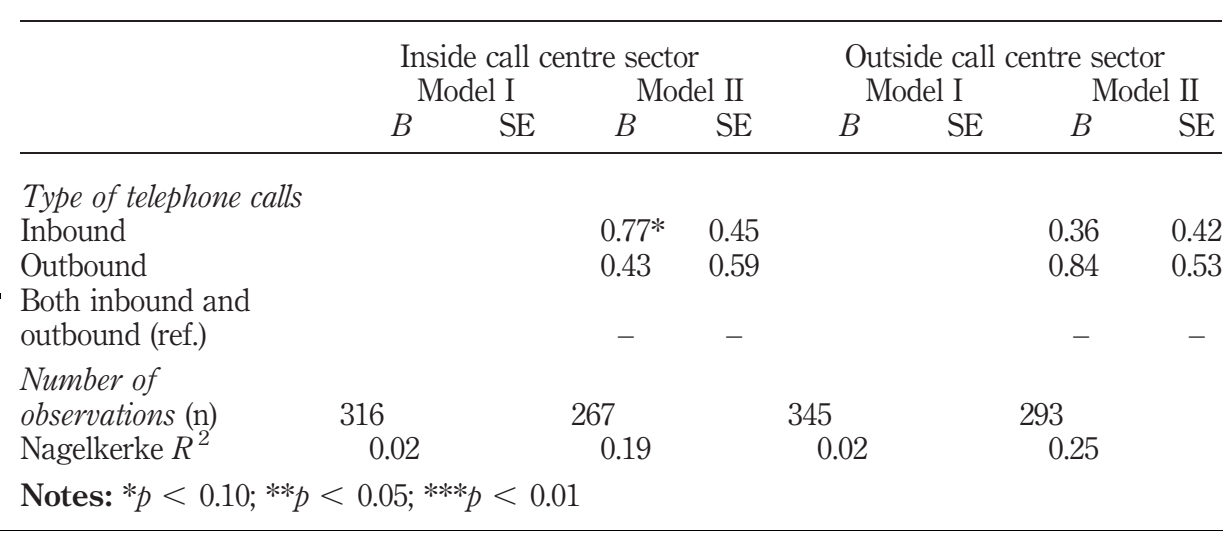

skills are also important for workers' ability to work in another call centre. Gaps on sector-specific or firm-specific skills do not influence the agents' perceived labour market perspectives. Other variables turn out to be not significant either, with the exception of working in a call centre where inbound telephone calls are made.

The last column of Table IV presents the results for the perceived labour market perspectives of call centre agents outside the sector. Again, general, sector-specific, or firm-specific training have no significant affect the option-value of agents in the labour market. Work experience does not affect this either, which can be explained by the fact that the accumulated skills during work life may be quite firm and sector-specific. Age seems to be important though, since younger agents think it to be less difficult to find an equally attractive job outside the sector than older agents. Lower educated agents perceive their labour market perspectives outside the sector as less good, as do call centre agents with gaps in general skills. This points to the phenomenon that older and lower educated workers have more difficulty of finding a job in general.

\section{Effects of training on the inclination to quit}

The inclination to quit is measured by asking call centre agents whether they consider accepting a job in another firm inside or outside the sector within two years. A total 5 per cent of the agents indicate an inclination to quit for a job at another call centre, mainly because they think that career opportunities are better and wages are higher elsewhere. Almost one-third of all call centre agents consider accepting a job outside the sector. The main reasons are the better career opportunities elsewhere and the present work being not satisfying.

Table $\mathrm{V}$ shows the estimation results of our analyses in the determinants of workers' expectations to accept a job in another firm. The results of 


\begin{tabular}{|c|c|c|c|c|c|c|c|c|c|}
\hline & Insid & call c & ntre sector & & Outsi & e call & centre secto & & I raining and \\
\hline & Model & & Model & & Model & & Model & & \\
\hline & $B$ & $\mathrm{SE}$ & $B$ & $\mathrm{SE}$ & $B$ & $\mathrm{SE}$ & $B$ & $\mathrm{SE}$ & \\
\hline Intercept & $-3.06^{* * *}$ & 0.35 & -0.73 & 2.31 & $-0.83^{* * *}$ & 0.16 & $-2.71 * *$ & 1.10 & \\
\hline $\begin{array}{l}\text { Training } \\
\text { General }\end{array}$ & 0.43 & 0.55 & 0.67 & 0.66 & $0.48^{*}$ & 0.28 & -0.17 & 0.38 & 267 \\
\hline Sector-specific & 0.48 & 0.55 & -0.01 & 0.65 & $-0.48^{*}$ & 0.28 & -0.27 & 0.38 & \\
\hline Firm-specific & -0.76 & 0.57 & $-1.40 * *$ & 0.71 & 0.20 & 0.28 & 0.51 & 0.37 & \\
\hline Sex & & & & & & & & & \\
\hline Female & & & 0.92 & 0.69 & & & $-0.54^{*}$ & 0.32 & \\
\hline Male (ref.) & & & - & - & & & - & - & \\
\hline Age(years) & & & & & & & & & \\
\hline Less then 25 & & & -0.49 & 0.97 & & & $2.00 * * *$ & 0.53 & \\
\hline $26-40$ & & & 0.74 & 0.81 & & & 0.53 & 0.48 & \\
\hline 40 and older (ref.) & & & - & - & & & - & - & \\
\hline Work experience & & & & & & & & & \\
\hline In years & & & $1.20 * *$ & 0.54 & & & 0.01 & 0.11 & \\
\hline In years ${ }^{2}$ & & & $-0.14^{* *}$ & 0.07 & & & -0.01 & 0.00 & \\
\hline Working hours & & & & & & & & & \\
\hline Part-time job & & & -0.52 & 0.65 & & & $0.82^{* *}$ & 0.32 & \\
\hline Full-time job (ref.) & & & - & - & & & - & - & \\
\hline Type of contract & & & & & & & & & \\
\hline Permanent & & & -1.05 & 0.70 & & & $-0.71^{* *}$ & 0.33 & \\
\hline Temporary (ref.) & & & - & - & & & - & - & \\
\hline Educational level & & & & & & & & & \\
\hline Lower & & & -0.36 & 1.14 & & & $-1.68 * * *$ & 0.57 & \\
\hline Middle & & & 0.54 & 0.76 & & & $-1.19 * * *$ & 0.40 & \\
\hline Higher (ref.) & & & - & - & & & - & - & \\
\hline Field of study & & & & & & & & & \\
\hline General & & & -1.17 & 0.79 & & & 0.46 & 0.43 & \\
\hline Economics & & & $-1.40^{*}$ & 0.75 & & & -0.09 & 0.39 & \\
\hline Other (ref.) & & & - & - & & & - & - & \\
\hline Skill gaps & & & & & & & & & \\
\hline General & & & -0.42 & 0.65 & & & $-0.61^{*}$ & 0.32 & \\
\hline Sector-specific & & & 0.59 & 0.57 & & & 0.23 & 0.33 & \\
\hline Firm-specific & & & 1.21 & 0.76 & & & 0.39 & 0.40 & \\
\hline $\begin{array}{l}\text { Type of contact } \\
\text { centre }\end{array}$ & & & & & & & & & \\
\hline In-house & & & 0.27 & 1.51 & & & $2.81^{* * * *}$ & 0.82 & \\
\hline Outsourcing (ref.) & & & - & - & & & - & - & Table V. \\
\hline Number of & & & & & & & & & $\begin{array}{l}\text { Kesuits of logistic } \\
\text { regression analyses on }\end{array}$ \\
\hline $\begin{array}{l}\text { employees } \\
100 \text { or less }\end{array}$ & & & $318 * *$ & 092 & & & $086 * * *$ & 04 & inclination to quit for \\
\hline $101-200$ & & & $2.08^{* * *}$ & 1.21 & & & $2.41 * * *$ & 0.47 & another job inside and \\
\hline & & & & & & & $\int(c 0 n)$ & & sector (within two \\
\hline
\end{tabular}


JEIT

$28,2 / 3 / 4$

268

Table V.

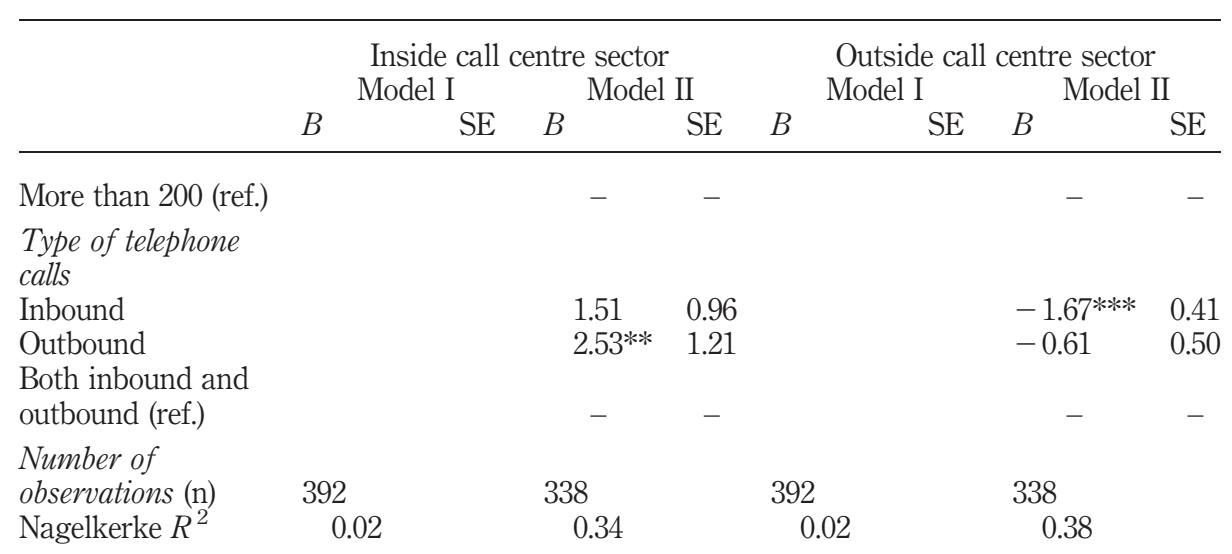

Notes: $* p<0.10 ; * * p<0.05 ; * * * p<0.01$

Model I show that training does not influence the inclination to quit for another job inside the sector. However, after including worker, job, and firm characteristics, firm-specific training seems to decrease this inclination. This is in line with $\mathrm{Hla}$ that in order to profit from this kind of training, agents have to stay employed in the firm, since firm-specific skills cannot be deployed in other firms. In addition, work experience increases the probability of considering another job inside the call centre sector. Agents with many years of experience, however, are again more committed to their present job. Skill gaps do not influence the inclination to quit for a job in another call centre. Agents with an initial education in an economic field of study are less likely to accept another job inside the sector. Looking at the firm characteristics, we see that large call centres apparently are attractive employers, for agents working in small firms (200 employees or less) are more inclined to quit for a job at another call centre. Agents working in call centres where only outbound phone calls are made, are also more inclined to leave. This has probably to do with the fact that outbound phone calls usually are much more stressful for the agents than inbound calls.

Finally, we turn to the results for the inclination to quit for a job outside the sector. In the first instance, our $H 2 b$ and $H 3 b$ on sector-specific training and general training seem to hold. Agents who followed sector-specific training are less likely to consider another job outside the sector, whereas agents who participated in general training are more likely to do so. However, after controlling for worker, job, and firm characteristics, training no longer has a significant effect on job commitment. Women, agents with a permanent contract and lower educated agents are less inclined to quit for a job outside the sector. Younger agents and agents who work part time on the other hand are less committed to their job and thus more inclined to 
consider a job outside the sector. It is quite remarkable that work experience does not play a significant role here. Agents with gaps in general skills, as expected, are less likely to accept a job outside the sector. Finally, firm characteristics appear to be quite important in predicting job commitment. Agents working in in-house contact centres, in medium-sized firms (100-200 employees), or in call centres where both inbound and outbound phone calls are made, are more inclined to quit for a job outside the sector.

\section{Conclusions}

Our results show that training does not significantly affect the perceived labour market perspectives of call centre agents. Agents who participated in general, sector-specific or firm-specific training do not estimate their option-value in the labour market to be higher than agents who did not participated in training. Moreover, training does not influence expected job mobility within or outside the call centre sector. The inclination to quit the present job within two years is the same for agents with and without training. There is one exception, however. In line with the predictions of human capital theory $(H 1 a)$, agents who participated in firm-specific training significantly less consider a job in another call centre than agents who did not.

All this is good news for firms offering general, sector-specific, and firm-specific training, since their investments will not increase the expected job mobility of call centre agents. Another finding, however, might be more problematic for call centres. The work experience of agents positively affects their labour market perspectives inside the sector. In addition, agents with more experience are more inclined to quit for a job in another call centre. This means that firms need to keep their employees satisfied, otherwise they will apply for a job at their competitor's. Experienced workers will not be lost for the sector as a whole, though, since work experience does not influence the labour market perspectives of call centre agents outside the sector, nor their inclination to consider another job outside the sector.

At this point, it should be noted that this study also has its limitations. First of all, we focus on expected job mobility, that is on the perceived difficulty to find an equally attractive job and on the quitting intentions of call centre workers. These two aspects of expected job mobility are closely related to the concept of job commitment. Research showed that quitting intentions often lead to actual turnover (e.g. Shields and Ward, 2001), but the relationship between expected and actual mobility is not perfect. Moreover, the data are collected in call centres in the region Arnhem/Nijmegen in The Netherlands. It would be interesting to study whether the relationship between general, sector-specific, and firm-specific
Training and expectations 
JEIT

$28,2 / 3 / 4$

270

training and expected job mobility found here also hold for other countries, and for other sectors of industry.

Another important point to note is that the relationship between training and mobility is quite complex. Agents do not follow training at random. Those who are more committed to the firm, are more likely to follow training and are also less likely to quit. We tried to deal with this bias by including a number of important worker and job characteristics that influence both training and mobility in our analysis. At the firm level, selectivity occurs when firms offering training have a low personnel turnover because they invest in other fields, like management quality, as well (see Zwick, 2002). Or, the other way around, when firms with a low training participation also have poor working conditions and, thus, a high turnover. This notion of selectivity pleads for a more broad view when looking at training in a firm. HRM practices play an important role in this. Ichniowski et al. (1997), for instance, find that the effects of investments in training are lower when these investments are not combined with complementary HRM practices. More recently, several authors focus on the relevance of a high performance workplace (HPW) in which the firm focuses on the quality of its workforce (e.g. Wolf and Zwick, 2002). The HPW is assumed to be related to the technological and organisational innovativeness of the firm (see Black and Lynch, 2001; Wolf and Zwick, 2002). Since these innovations often also lead to both training and mobility, they deserve more attention in future research on the relationship between training and job mobility.

\section{Notes}

1. Call centre agents work in the heart of a call centre. In this so-called contact centre, the telephonic conversations with customers take place.

2. The data were gathered by ROA/ESKAN for the project "Recruitment, Competencies and Perspectives of Call Centre Agents" (De Grip and Sieben, 2001).

3. The exception is gross monthly income.

4. About 60 to 80 per cent of all call centres in The Netherlands are in-house call centres (Braaksma, 1998).

\section{References}

Acemuglu, D. and Pischke, J-S. (1998), "Why do firms train? Theory and evidence", Quarterly Journal of Economics, Vol. 113, pp. 79-119.

Acemuglu, D. and Pischke, J.-S. (1999), "Beyond Becker: training in imperfect labour markets", Economic Journal, Vol. 109, pp. F112-42.

Becker, G.S. (1962), "Investment in human capital: a theoretical analysis", Journal of Political Economy, Vol. 70, pp. 9-49.

Black, S.E. and Lynch, L.M. (2001), "How to compete: the impact of workplace practices and information technology on productivity", The Review of Economics and Statistics, Vol. 83, pp. 434-45.

Braaksma, R.M. (1998), Bedrijfsleven in beeld: Callcenters (Business in the Picture: Call Centres), EIM, Zoetermeer. 
De Grip, A., Heijke, H. and Willems, E. (1998), “Training and mobility”, The Netherlands Journal of Social Sciences, Vol. 34, pp. 78-98.

De Grip, A. and Sieben, I. (2001), Klantcontact. Rekrutering, competenties en perspectieven van medewerkers in callcenters, [Recruitment, Competencies and Perspectives of Call Centre Agents], ROA-R-2001/9, Maastricht.

Dothan, U. and Williams, J. (1991), "Education as an option", Journal of Business, Vol. 54, pp. $117-39$.

Franz, W. and Soskice, D. (1995), “The German apprenticeship system”, in Buttler, F., Franz, W., Schettkat, R. and Soskice, D. (Eds), Institutional Frameworks and Labor Market Performance, Routledge, London and New York, NY.

Ichniowski, C., Shaw, K. and Prennnushi, G. (1997), "The effects of human resource management practices on productivity: a study of steel finishing lines", American Economic Review, Vol. 87, pp. 291-312.

NCCBP (2001), Nationaal Contact Center Benchmark Onderzoek 2001 (National Contact Centre Benchmark Survey 2001), NCCBP/MarketResponse, Amersfoort.

ROA (2000), Werkgelegenheid en Scholing 1999 (Employment and Training 1999), ROA, Maastricht.

Rose, E. (2002), "The labour process and union commitment within a banking services call centre", The Journal of Industrial Relations, Vol. 44, pp. 40-61.

Shields, M.A. and Ward, M.E. (2001), "Improving nurse retention in the National Health Service in England: the impact of job satisfaction on intentions to quit", Journal of Health Economics, Vol. 20, pp. 677-90.

Stevens, M. (1994), “A theoretical model of on-the-job training with imperfect competition”, Oxford Economic Papers, Vol. 46, pp. 537-62.

Stevens, M. (1999), "Human capital theory and UK vocational training policy", Oxford Review of Economic Policy, Vol. 15, pp. 16-32.

Stromback, T. (2002), "Training and mobility", paper prepared for a seminar of the Labour Economics Group at Oxford University, March.

Wolf, E. and Zwick, T. (2002), Reassessing the Impact of High Performance Workplaces, Discussion Paper No. 02-07, ZEW, Mannheim.

Zwick, T. (2002), Training and Firm Productivity, Panel Evidence for Germany, Research Paper No. 23, ESRC Centre on Skills, Knowledge and Organisational Performance (SKOPE), Oxford. 